\title{
The Degree of Employment of Faculty Members for Assessment Standards Defined by the American Educational Organizations in Assessing Student Learning at the University of Najran
}

\author{
Raafat Kabil ${ }^{1}$, Yahya Bani Abduh ${ }^{1,2, *}$ \\ ${ }^{1}$ Department of Psychology, Faculty of Arts, Sohag UN, Deanship of Development and Quality, Najran University, \\ Kingdom of Saudi Arabia \\ ${ }^{2}$ Deanship of Development and Quality, Najran University, Kingdom of Saudi Arabia
}

Copyright $\bigcirc 2017$ by authors, all rights reserved. Authors agree that this article remains permanently open access under the terms of the Creative Commons Attribution License 4.0 International License

\begin{abstract}
This study investigates the faculty members' employment of assessment standards defined by the American educational organizations (NCME, AFT and NEA) to assessing student learning at the University of Najran from the students' point of view. To achieve the objective of the study, the questionnaire which consisted of 38 items distributed to seven standards was administered to 323 male and female students at some colleges. The results showed moderate level of the faculty members' employment of assessment standards. There were also statistically significant differences according to gender in favor of males and college in favor of practical college.
\end{abstract}

Keywords Assessment, Standards, American Educational Organization, AFT, NCME, NEA

\section{Introduction}

Modern educational systems that are able to cope with the rapid developments and the challenges imposed on require that the faculty members must master basic skills. Student learning assessment skill is the most important in the the process of learning and education and the most closely associated with educational development that seeks many different philosophies of education systems. It can enable teachers to judge the effectiveness of the process of learning and education in relation to learning outcomes and their relevance to students ' levels and skills development. While the educational objectives theory refers to undesirable changes in behavioral patterns for students to acquire the desired learning, the assessment aims to determine the degree and amount of changes that occur in educational performance through various methods.

The modern education assessment includes alternative assessment strategies based on scientific principles and methodologies to ensure the quality of the educational process [1, 2, 3, 4 and 5] as well as the need for diversity in modern assessment methods. Therefore, not only the approved assessment method on paper and pencil is common in many schools and universities, but also the use of other assessment methods based on performance, such as presentation, demonstration, communication, projects, assignments, quizzes, classroom activities, and observing the student behavior in the classroom, and in Laboratories. However, it should be taken in consideration the longer goal of educational evaluation of students to know how to save their knowledge and most importantly how the learner employs what he learns through real situations [6].

The previous studies $[7,8,9,10,11,12,13,14,15,16,17$, $18,19 \& 5$ ] indicate the various degrees of estimation methods inside the classroom by faculty members when assessing according to the criteria and educational foundations of modern adopted by modern educational organizations. However, the teachers' use of evaluation methods based on paper and pencil is high, while their use of methods that apply performance-based assessment, observation, and communication is medium. In addition, check list, rating scale, rubric, learning log anecdotal record registered low levels. Accordingly, the use of modern methods has been influenced by gender in favor of females, where studies have recommended that estimation methods that depend on performance rather than traditional methods (pen and paper) to ensure the overall quality of education.

In 1990, collaboration was made by American Federation of Teachers (AFT), National Council for Educational Measurement (NCME), and National Association of 
Educational (NEA) to identify standards for teachers to assess students. Seven standards were recognized for student learning assessment practices. Teachers are required to know how to apply these practices in order to improve the teaching process, enrich the students' learning, and achieve the expected levels of education. Especially, many teachers lack the necessary knowledge, skills, and good practices to assess their students, then judge students' performance, and they need to understand the relationship between the quality of assessment and its impact on teaching and learning processes [20].

In the Arab world, several countries have moved towards the development of standards of teacher performance. For example, the project of education development was launched in the kingdom of Saudi Arabia in 2005, aimed at the development of public education, where a team of educators [21] investigated standards professionally for teacher performance, and the eleventh criterion for evaluation urges teachers to use appropriate methods and tools in the educational measurement and evaluation. [22].

The Assessment, according to modern standards and educational foundations sponsored by modern educational organizations, reflects the achievements of the learner which were measured in real situations; where students are allowed to become integrated into the important tasks, consistent with their capacity, taking into account the individual differences of patriotism and the real assessment of students provoking high thinking skills (understand, analyze, criticize), and application, creativity, and problem solving. [23] The most alternative assessment methods used by many scientists in the field of education require that students raise levels of thinking and problem-solving skills to make students able to innovate. [24, 25].

Many previous studies [26, 27, 28, 29, 30 and 31] have been conducted in order to identify the degree of employment of contemporary assessment standards in student learning, and showed that the degree of employment by faculty members at the University of Najran has been achieved moderately, whereas the results of the study of [9 and 32] showed low level of employment of international standards for scientific education assessment standards in assessing student learning.

Another study was conducted by [21] to higher teachers' estimation of the degree of their commitment to the standards of student learning and the results showed on the impact of sex differences to the existence of significant differences in the degree of commitment in favor of female. In addition, the assessment process is considered the main factor that encourages the faculty members in the educational institution to improve their performance and educational outcomes $[33,34]$.

A study by [33] has also shown that teachers 'performance has improved with the use of assessment of students' performance-based standards, and the principals realized that the performance standards provide feedback to teachers and learners with high credibility compared to traditional methods of assessment earlier.

[34] held study to identify the availability of standards of quality in measuring student achievement tools in accordance with the overall quality standards and knowledge of measurement and evaluation tools that can be developed to measure student achievement. The study showed that there were not quality standards in measuring student achievement tools, as well as the existence of differences in developing tools to measure student achievement variable depending on experience in favor of their experience of 11 years and above.

It is clear from the foregoing that there is variation in the results of previous studies concerning the degree of use of modern methods of estimation by faculty members at the student assessment. In addition, the results of previous studies agree that the most commonly used method of assessment in the classroom is pen and paper compared with the methods of estimation methods to other alternative methods which require the need for diversification in the assessment of students to ensure the overall quality of teaching methods.

\subsection{Study Problem}

The world witness around us developing for The concept of the assessment of student learning, and its strategies and tools which requires teachers in different specialties using modern and alternative assessment strategies to measure learning outcomes, in addition to the keenness of Najran University on the importance of student assessment according to standardized criteria which have to be clear and declared within the strategic plan of the university This was a strong justification for conducting the current study in order to identify the degree of employment of faculty members for assessment standards defined by the American educational organizations to ensure An objective assessment of student learning, And especially many of the faculty members at the university are not qualified in the field of assessment of student learning.

In light of the above, the present study problem can be identified by the following questions:

1. What is degree of employment of faculty members for assessment standards defined by the American educational organizations (NCME, AFT and NEA) in assessing student learning at the University of Najran from the view of point of students?

2. Are there any statistically significant differences in the faculty members' employment of assessment standards defined by the American educational organizations [ NCME , AFT and NEA ] in assessing student learning at the University of Najran according to the gender variable [student males/ student females]?

3. Are there any statistically significant differences in the faculty members' employment of assessment standards defined by the American educational organizations [NCME , AFT and NEA ] in assessing student learning 
at the University of Najran According to the college variable [Practical college / Theoretic college]?

\subsection{Importance of the Study}

1. This study provides information for faculty's practices, which they use in assessing the learning of their students.

2. Assisting competent authorities in Najran University to make decisions about the degree of commitment of faculty members with student learning assessment standards and determine the strengths and weaknesses of the assessment practices in light of modern educational assessment standards.

3. Providing a measuring tool to assess student-learning standards, which provides an opportunity to measure the degree of commitment of faculty members to those standards.

\subsection{Terminology of Study}

Classroom assessment is one of the most hotly debated topics in educational circles. These debates appear not only in the professional literature but in the popular press as well. Assessment is a process of obtaining information in order to make decisions about the curriculum, students learning, program, and educational politics. Because of the complexity of the classroom situation and the diversity of the teaching and educational goals Faculty member treats with a large number of variables to provide a integrated description of aspects of the of student's personality or a description of his abilities, aptitudes and attitudes in quantitative or qualitative. In this regard, educational literature pointes to a different number of tools and methods that can be used by the teacher in the measurement of students' learning and their evaluation [2].

It should be noted that many of the countries in the educational systems tended to leave the traditional evaluation that depends only on paper and pen test, and depending on realistic evaluation through assignments for students which motivate the students to search, investigate and carry out experiments process.

The decision-making process in various fields, especially in the field of education depends on the use of the figure who holds the quantitative significance for the traits and this is what refers to the concept of measurement, where the measurement includes the determination of a class of numbers or symbols corresponding to the class of traits or characteristics in accordance with specific rules well defined. While the concept of Assessment is the process of gathering information to monitor progress and make educational decisions if necessary. Therefore, it focuses on learning, teaching and outcomes. Assessment is an interactive process between students and faculty that informs faculty how well their students are learning what they are teaching. The information is used by faculty to make changes in the learning environment, and is shared with students to assist them in improving their learning and study habits. This information is learner-centered, course based, frequently anonymous, and not graded. Whereas the evaluation focuses on grades and may reflect classroom components other than course content and mastery level. These could include discussion, cooperation, attendance, and verbal ability. Accordingly, the measurement, assessment and evaluation are considered interrelated concepts cannot be separated from one another [38].

Recently [16], a cooperative effort by the American Federation of faculty members, the National Council on Measurement in Education, and the National Education Association resulted in the development of a list of standards for teacher competence in educational assessment of students. These standards are intended to guide the preservice and in-service training of educators, the accreditation of preparation programs, and the future certification of all educators.

By establishing these standards for teacher competence in student assessment, the associations subscribe to the view that student assessment is an essential part of teaching and that effective teaching cannot exist without appropriate student assessment. The seven standards articulating teacher competence in the educational assessment of students are highlighted in the following paragraphs [16]:

1. Faculty members should be skilled in choosing assessment options appropriate for instructional decisions. Assessment options are quite diverse and include text-embedded and curriculum-embedded questions and tests, standardized criterion and norm-referenced tests, oral questions, spontaneous and structured performance assessment, portfolios, exhibitions, demonstration, rating scales, writing samples, paper-pencil tests, seatwork and homework, peer and self-assessments, student records, observations, questionnaires, interviews, and projects and products.

2. Faculty members should be skilled in developing assessment methods appropriate for instructional decisions. So the faculty members must be able to determine the quality of the assessment tools they develop.

3. Faculty members should be skilled in administering, scoring, and interpreting the results of both commercially produced and teacher-produced assessment methods. This standard simply recognizes that good tools can be used inappropriately.

4. Faculty members should be skilled in using assessment results when making decisions about individual students, planning teaching, and developing curriculum. This principle recognizes that faculty members are in a position to make educational decisions. This decision-making involves judgments that directly affect the lives of a number of people. Consequently, these judgments should be as reliable and valid as possible. 
5. Faculty members should be skilled in developing valid student grading procedures that use student assessments. Faculty members who meet this standard will have the conceptual and application skills that follow. They will be able to devise, implement, and explain a procedure for developing grades composed of marks from various assignments, projects, in-class activities, quizzes, tests, and or other assessments. Faculty members will understand and be able to articulate why the grades they assign are rational, justified, and fair, acknowledging that such grades reflect their preferences and judgment. Faculty members will be able to recognize and avoid faulty grading procedures such as using grades as punishment.

6. Faculty members should be skilled in communicating assessment results to students, parents, other lay audiences, and other educators. Faculty members will be able to explain that assessment results do not imply such background factors limit a student's ultimate educational development. They must able to communicate to students and assess the student's educational progress. Faculty members must able to understand and explain the importance of considering measurement errors when using assessments to make decisions about individual students.

7. Faculty members should be skilled in recognizing unethical, illegal, and otherwise inappropriate assessment methods and uses of assessment information.. Faculty members have to be aware that various assessment procedures can be misused or overused, resulting in harmful consequences such as embarrassing students, violating a student's right to confidentiality, and inappropriately using student's standardized achievement test scores to measure teaching effectiveness (AFT, NCME, NEA, 1990).

American Educational Assessment standards: the skills of understanding and application of the faculty for student learning and assessment standards established by the American educational organizations (NCME, AFT, NEA) [1990] under seven standards [16].

\section{Materials and Methods}

\subsection{Population and Sample}

The current study was based on a descriptive approach, which is compatible to the nature of the study and its objectives.

\subsection{Population and Sample}

Study population consisted of students of the University of Najran, Saudi Arabia and enrolled for the academic year 2016/2017.
The study sample consisted of (323) students, selected by a simple random Method, distributors according to the study variables as the table [1] Shows:

Table 1. The frequencies and percentages of the sample according to study variables

\begin{tabular}{|c|c|c|c|}
\hline Variables & Categories & Repetition & Ratio \% \\
\hline Gender & Males & 182 & 56.3 \\
\hline \multirow{2}{*}{ Collage } & Females & 141 & 53.7 \\
\cline { 2 - 4 } & Practical & 181 & 56.03 \\
\hline & Theoretical & 142 & 53.97 \\
\hline & Total & 323 & 100.0 \\
\hline
\end{tabular}

\subsection{Study Instrument}

Based on the theoretical literature on the assessment of student learning according to the standards and educational foundations of modern, assessment standards which were defined by the American educational organizations: American Federation of Teachers (AFT), The National Council on Measurement in Education (NCME), and The National Education Association (NEA), the seven assessment standards of the practices of assessing student learning were chosen as teachers be known, understood and applied in order to achieve the quality of learning process.

A questionnaire was developed consisting of [38] items on a scale Likert quintet to respond [very highly, highly, moderately, low degree, very low degree]. Items are distributed to the seven standards as follows :the first standard: faculty members should be skilled in choosing assessment options appropriate for instructional decisions, (Items $1-4$ ), the second standard: faculty members should be skilled in developing assessment methods appropriate for instructional decisions, (Items $5-10$ ), the third standard: faculty members should be skilled in administering, scoring, and interpreting the results of both commercially produced and teacher-produced assessment methods,(Items 11-19), the fourth standard: faculty members should be skilled in employment assessment results when making decisions about improvement planning teaching, developing curriculum, improve academic performance, (Items 20-24), the fifth standard: faculty members should be skilled in developing valid student grading procedures that use student assessments (Item 25-27), the sixth standard: faculty members should be skilled in communicating assessment results to students, and To whom it may concern, (Items 28-33), the seventh standard: faculty members should be skilled in recognizing unethical, illegal, and otherwise inappropriate assessment methods and uses of assessment information (Items 34-38).

\subsection{Validity of the Tool}

\subsubsection{Content Validity}

The first draft of the questionnaire was modified by [6] experts at collage of education in the field of measurement 
and evaluation at Najran University. Their guidance and suggestions to add, delete and edit items have been taken in consideration, where the ratio is considered agreement arbitrators $(80 \%)$ belong to the item of the standard. The final draft of the questionnaire consisted of (38) items distributed to seven standards.

\subsubsection{Internal Consistency Validity}

To examine the internal consistency validity of the questionnaire used in the current study, the questionnaire was administered to an exploratory sample of students at the University of Najran, consisting of (89) students, Table 2 shows the results.

Results in [Table 2] show that the Pearson correlation coefficients are statistically significant at the level of values (0.01) between items and sub-scales, as well as between items with total scale, sub-scales with the total scale, which indicates to internal consistency validity of the questionnaire.

\subsection{The Reliability of the Questionnaire}

To examine the reliability of the questionnaire, the Cronbach's Alpha was calculated. This technique revealed a high reliability coefficient [0.86]. In addition, the reliability of the questionnaire was estimated through using Test retest method. This technique revealed a high reliability coefficient (0.92) as Table [3] shows.

\section{Results}

\subsection{Regarding Research Question One}

Degree of employment of faculty members for assessment standards defined by the American educational organizations ( NCME , AFT and NEA ) in assessing student learning at the University of Najran from the view of point of students.

To identify the degree of employment of faculty members to the assessment standards defined by the American educational organizations (NCME, AFT and NEA) in assessing student learning at the University of Najran, means and standards deviations were calculated as shown in table [4].

Table (4) shows moderated level of employment of faculty members for assessment standards defined by the American educational organizations (NCME, AFT and NEA) in assessing student learning at the University of Najran from the view of point of students. $(\mathrm{M}=3.08),(\mathrm{SD}=0.79)$. The averages of standards were between 3.20 to 2.97 . The second standard [developing assessment methods appropriate for instructional decisions] was ranked first $(\mathrm{M}=3.20)$, $(\mathrm{SD}=(1.12)$ while the sixth stander [communicating assessment results to students, parents, other lay audiences, and other educators] occupied the last rank $(M=2.97)$, $\mathrm{SD}=(0.99)$.

\subsection{Regarding Research Question Two}

Statistically significant differences in the employment of faculty members for assessment standards defined by the American educational organizations ( NCME, AFT and NEA ) in assessing student learning at the University of Najran According to the gender variable (student males / student females).

To identify Statistically significant differences among students' responses(student males, $\mathrm{n}=182$ / student females, $\mathrm{n}=141$ ) for in the employment of faculty members for assessment standards defined by the American educational organizations (NCME, AFT and NEA ) in assessing student learning, means, standards deviations and $\mathrm{T}$. test were calculated as shown in table [5].

The table [5] shows that are statistically significant differences in the faculty members' employment of assessment standards defined by the American educational organizations ( NCME, AFT and NEA ) in assessing student learning at the University of Najran According to the gender variable in favor of student males $[\alpha \leq 0.05]$.

\subsection{Regarding Research Question Three}

Statistically significant differences in the employment of faculty members for assessment standards defined by the American educational organizations ( NCME, AFT and NEA ) in assessing student learning at the University of Najran According to the college variable [Practical college / Theoretic college].

To identify Statistically significant differences among students' responses (Practical colleges, $n=181 /$ Theoretic colleges, $n=142$ ) for in the employment of faculty members for assessment standards defined by the American educational organizations (NCME, AFT and NEA ) in assessing student learning, means, standards deviations and T. test were calculated as shown in table (5).

The table [6] shows that are statistically significant differences in the employment of faculty members for assessment standards defined by the American educational organizations ( NCME, AFT and NEA ) in assessing student learning at the University of Najran According to the college variable in favor of Practical colleges $(\alpha \leq 0.05)$. 
Table 2. Internal consistency validity- Pearson correlation coefficient[ $\mathrm{N}=89$ ]

\begin{tabular}{|c|c|c|c|c|c|c|c|c|}
\hline \multirow[b]{2}{*}{ No. standard items } & \multicolumn{8}{|c|}{ No. of standards } \\
\hline & Standard 1 & $\begin{array}{c}\text { Standard } \\
2\end{array}$ & Standard 3 & Standard 4 & $\begin{array}{c}\text { Standard } \\
5\end{array}$ & $\begin{array}{c}\text { Standard } \\
6\end{array}$ & $\begin{array}{c}\text { Standard } \\
7\end{array}$ & Total score \\
\hline Standard 1[Item a1-4] & 1 & $.596^{* *}$ & $.449^{* *}$ & $-.024-$ & $.525^{* *}$ & $.506^{* *}$ & $.271^{*}$ & $.651^{* *}$ \\
\hline a1 & $.961^{* *}$ & $.578^{* *}$ & $.409^{* *}$ & .031 & $.518^{* *}$ & $.473^{* *}$ & $.260^{*}$ & $.629^{* *}$ \\
\hline $\mathrm{a} 2$ & $.974^{* *}$ & $.578^{* *}$ & $.417^{* *}$ & $-.042-$ & $.506^{* *}$ & $.480^{* *}$ & $.258^{*}$ & $.623^{* *}$ \\
\hline a3 & $.909^{* *}$ & $.537^{* *}$ & $.470^{* *}$ & $-.042-$ & $.482^{* *}$ & $.482^{* *}$ & $.259^{*}$ & $.604^{* *}$ \\
\hline a4 & $.953^{* *}$ & $.571^{* *}$ & $.409^{* *}$ & $-.035-$ & $.488^{* *}$ & $.486^{* *}$ & $.253^{*}$ & $.615^{* *}$ \\
\hline Standard 2 [Item B5-B10] & $.596^{* *}$ & 1 & $.743^{* *}$ & .079 & $.835^{* *}$ & $.795^{* *}$ & $.574^{* *}$ & $.919^{* *}$ \\
\hline B5 & $.671^{* *}$ & $.833^{* *}$ & $.565^{* *}$ & .071 & $.659^{* *}$ & $.635^{* *}$ & $.434^{* *}$ & $.769^{* *}$ \\
\hline B6 & $.566^{* *}$ & $.948^{* *}$ & $.649^{* *}$ & .080 & $.739^{* *}$ & $.707^{* *}$ & $.480^{* *}$ & $.836^{* *}$ \\
\hline B7 & $.538^{* *}$ & $.947^{* *}$ & $.727^{* *}$ & .128 & $.824^{* *}$ & $.771^{* *}$ & $.593^{* *}$ & $.895^{* *}$ \\
\hline B8 & $.526^{* *}$ & $.931^{* *}$ & $.686^{* *}$ & .047 & $.772^{* *}$ & $.796^{* *}$ & $.622^{* *}$ & $.874^{* *}$ \\
\hline B9 & $.437^{* *}$ & $.891^{* *}$ & $.713^{* *}$ & .071 & $.763^{* *}$ & $.689^{* *}$ & $.486^{* *}$ & $.804^{* *}$ \\
\hline $\mathrm{B} 10$ & $.493^{* *}$ & $.897^{* *}$ & $.713^{* *}$ & .031 & $.795^{* *}$ & $.735^{* *}$ & $.516^{* *}$ & $.828^{* *}$ \\
\hline Standard 3 [Item c11-c19] & $.449^{* *}$ & $.743^{* *}$ & 1 & .152 & $.715^{* *}$ & $.617^{* *}$ & $.456^{* *}$ & $.793^{* *}$ \\
\hline $\mathrm{C} 11$ & $.519^{* *}$ & $.864^{* *}$ & $.761^{* *}$ & .124 & $.816^{* *}$ & $.775^{* *}$ & $.533^{* *}$ & $.867^{* *}$ \\
\hline $\mathrm{C} 12$ & $.522^{* *}$ & $.900^{* *}$ & $.774^{* *}$ & .106 & $.821^{* *}$ & $.742^{* *}$ & $.503^{* *}$ & $.862^{* *}$ \\
\hline $\mathrm{C} 13$ & $.494^{* *}$ & $.813^{* *}$ & $.822^{* *}$ & .056 & $.806^{* *}$ & $.726^{* *}$ & $.497^{* *}$ & $.829^{* *}$ \\
\hline $\mathrm{C} 14$ & $.458^{* *}$ & $.811^{* *}$ & $.764^{* *}$ & .047 & $.810^{* *}$ & $.748^{* *}$ & $.500^{* *}$ & $.818^{* *}$ \\
\hline $\mathrm{C} 15$ & $.355^{* *}$ & $.699^{* *}$ & $.643^{* *}$ & .047 & $.724^{* *}$ & $.604^{* *}$ & $.435^{* *}$ & $.691^{* *}$ \\
\hline $\mathrm{C} 16$ & .096 & $-.087-$ & $.372^{* *}$ & $-.143-$ & $-.079-$ & $-.095-$ & $-.081-$ & $.806^{* *}$ \\
\hline $\mathrm{C} 17$ & $-.004-$ & $-.064-$ & $.359^{* *}$ & $.343^{* *}$ & $-.039-$ & $-.131-$ & $-.024-$ & $.810^{* *}$ \\
\hline $\mathrm{C} 18$ & $-.121-$ & $-.038-$ & $.374^{* *}$ & .092 & $-.088-$ & $-.077-$ & .038 & $.806^{* *}$ \\
\hline $\mathrm{C} 19$ & .009 & .005 & $.242^{*}$ & .038 & $-.023-$ & $-.027-$ & $-.003-$ & $.810^{* *}$ \\
\hline Standard 4 [Item d20-d24] & $-.024-$ & .079 & .152 & 1 & .098 & .008 & $.244^{*}$ & $.209^{*}$ \\
\hline D20 & .207 & $.321^{* *}$ & $.344^{* *}$ & $.469^{* *}$ & $.358^{* *}$ & $.244^{*}$ & $.215^{*}$ & $.395^{* *}$ \\
\hline $\mathrm{D} 21$ & .204 & $.425^{* *}$ & $.470^{* *}$ & $.481^{* *}$ & $.431^{* *}$ & $.370^{* *}$ & $.333^{* *}$ & $.507^{* *}$ \\
\hline $\mathrm{D} 22$ & $-.163-$ & $-.072-$ & .012 & $.795^{* *}$ & $.470^{* *}$ & $-.095-$ & $-.021-$ & $.775^{* *}$ \\
\hline $\mathrm{D} 23$ & $-.136-$ & $-.094-$ & $-.076-$ & $.854^{* *}$ & $.470^{* *}$ & $-.161-$ & $-.104-$ & $.742^{* *}$ \\
\hline D24 & $-.099-$ & $-.147-$ & $-.068-$ & $.883^{* *}$ & $.370^{* *}$ & $-.191-$ & $-.097-$ & $.726^{* *}$ \\
\hline Standard 5 [Item e25-e27] & $.525^{* *}$ & $.835^{* *}$ & $.715^{* *}$ & .098 & 1 & $.876^{* *}$ & $.658^{* *}$ & $.915^{* *}$ \\
\hline E25 & $.472^{* *}$ & $.730^{* *}$ & $.646^{* *}$ & .102 & $.932^{* *}$ & $.778^{* *}$ & $.680^{* *}$ & $.837^{* *}$ \\
\hline E26 & $.521^{* *}$ & $.815^{* *}$ & $.705^{* *}$ & .081 & $.946^{* *}$ & $.841^{* *}$ & $.554^{* *}$ & $.873^{* *}$ \\
\hline E27 & $.499^{* *}$ & $.829^{* *}$ & $.681^{* *}$ & .093 & $.962^{* *}$ & $.871^{* *}$ & $.629^{* *}$ & $.891^{* *}$ \\
\hline Standard 6 [Item f28-f33] & $.506^{* *}$ & $.795^{* *}$ & $.617^{* *}$ & .008 & $.876^{* *}$ & 1 & $.761^{* *}$ & $.904^{* *}$ \\
\hline F28 & $.479^{* *}$ & $.784^{* *}$ & $.651^{* *}$ & $-.002-$ & $.856^{* *}$ & $.900^{* *}$ & $.713^{* *}$ & $.867^{* *}$ \\
\hline F29 & $.534^{* *}$ & $.817^{* *}$ & $.664^{* *}$ & .048 & $.877^{* *}$ & $.948^{* *}$ & $.662^{* *}$ & $.898^{* *}$ \\
\hline F30 & $.472^{* *}$ & $.768^{* *}$ & $.572^{* *}$ & .027 & $.840^{* *}$ & $.963^{* *}$ & $.749^{* *}$ & $.870^{* *}$ \\
\hline F31 & $.432^{* *}$ & $.708^{* *}$ & $.556^{* *}$ & .028 & $.815^{* *}$ & $.954^{* *}$ & $.726^{* *}$ & $.835^{* *}$ \\
\hline F32 & $.500^{* *}$ & $.751^{* *}$ & $.544^{* *}$ & $-.046-$ & $.803^{* *}$ & $.962^{* *}$ & $.731^{* *}$ & $.846^{* *}$ \\
\hline F33 & $.442^{* *}$ & $.662^{* *}$ & $.503^{* *}$ & $-.016-$ & $.753^{* *}$ & $.914^{* *}$ & $.715^{* *}$ & $.789^{* *}$ \\
\hline Standard 7 [Item g34-g38] & $.271^{*}$ & $.574^{* *}$ & $.456^{* *}$ & .062 & $.658^{* *}$ & $.761^{* *}$ & 1 & $.740^{* *}$ \\
\hline G34 & $.341^{* *}$ & $.590^{* *}$ & $.450^{* *}$ & .061 & $.658^{* *}$ & $.777^{* *}$ & $.930^{* *}$ & $.747^{* *}$ \\
\hline G35 & $.314^{* *}$ & $.576^{* *}$ & $.453^{* *}$ & .051 & $.651^{* *}$ & $.733^{* *}$ & $.929^{* *}$ & $.727^{* *}$ \\
\hline G36 & .205 & $.513^{* *}$ & $.407^{* *}$ & .071 & $.597^{* *}$ & $.710^{* *}$ & $.961^{* *}$ & $.677^{* *}$ \\
\hline G37 & .169 & $.481^{* *}$ & $.376^{* *}$ & .097 & $.563^{* *}$ & $.679^{* *}$ & $.911^{* *}$ & $.638^{* *}$ \\
\hline G38 & $.222^{*}$ & $.497^{* *}$ & $.432^{* *}$ & $-.001-$ & $.579^{* *}$ & $.621^{* *}$ & $.908^{* *}$ & $.636^{* *}$ \\
\hline Total score & $.651^{* *}$ & $.919^{* *}$ & $.793^{* *}$ & $.209^{*}$ & $.915^{* *}$ & $.904^{* *}$ & $.740^{* *}$ & 1 \\
\hline
\end{tabular}

**. Correlation is significant at the 0.01 level (2-tailed).

*. Correlation is significant at the 0.05 level (2-tailed). 
Table 3. Reliability estimation/Test-retest

\begin{tabular}{|c|c|c|c|}
\hline No. & Standards & $\begin{array}{l}\text { Coefficient } \\
\text { alpha }\end{array}$ & $\begin{array}{l}\text { Test-retest correlation } \\
\text { coefficientn= }(50)\end{array}$ \\
\hline 1 & $\begin{array}{l}\text { faculty members should be skilled in choosing assessment options appropriate for } \\
\text { instructional decisions }\end{array}$ & 0.76 & $0.84 *$ \\
\hline 2 & $\begin{array}{l}\text { faculty members should be skilled in developing assessment methods appropriate for } \\
\text { instructional decisions }\end{array}$ & 0.78 & $0.89^{*}$ \\
\hline 3 & $\begin{array}{l}\text { faculty members should be skilled in administering, scoring, and interpreting the results of } \\
\text { both commercially produced and teacher-produced assessment methods }\end{array}$ & 0.82 & $0.88^{*}$ \\
\hline 4 & $\begin{array}{l}\text { faculty members should be skilled in employment assessment results when making } \\
\text { decisions about improvement planning teaching, developing curriculum, improve } \\
\text { academic performance }\end{array}$ & 0.80 & $0.87^{*}$ \\
\hline 5 & $\begin{array}{l}\text { faculty members should be skilled in developing valid student grading procedures that use } \\
\text { student assessments }\end{array}$ & 0.75 & $0.80^{*}$ \\
\hline 6 & $\begin{array}{l}\text { faculty members should be skilled in communicating assessment results to students, and } \\
\text { To whom it may concern }\end{array}$ & 0.76 & $0.86^{*}$ \\
\hline \multirow[t]{2}{*}{7} & $\begin{array}{l}\text { faculty members should be skilled in recognizing unethical, illegal, and otherwise } \\
\text { inappropriate assessment methods and uses of assessment information }\end{array}$ & 0.80 & $0.88^{*}$ \\
\hline & total score & 0.86 & $0.92 *$ \\
\hline
\end{tabular}

Note. Test-retest coefficients are based on a subset sample of 50 .

$* \mathrm{p}<0.05$

Table 4. Means and standards deviations according to assessment standards defined by the American educational organizations (NCME, AFT and NEA)

\begin{tabular}{|c|c|c|c|c|}
\hline No & standards -Item & Mean & Std. Deviation & Levels \\
\hline \multicolumn{2}{|r|}{$\begin{array}{c}\text { The First standard: faculty members should be skilled in choosing assessment options appropriate for } \\
\text { instructional decisions }\end{array}$} & 2.98 & 1.19 & Moderate \\
\hline 1 & $\begin{array}{l}\text { A Faculty member don't use only a paper and pencil tests in the process of assessing students, } \\
\text { but uses other assessment methods }\end{array}$ & 3.06 & 1.31 & Moderate \\
\hline 2 & A Faculty member uses more than style to assess students' learning in the course & 3.03 & 1.30 & Moderate \\
\hline 3 & $\begin{array}{l}\text { A Faculty member keens on choosing the appropriate method of assessment, according to the } \\
\text { nature of the course [theoretical / practical] }\end{array}$ & 2.73 & 1.27 & Moderate \\
\hline 4 & $\begin{array}{l}\text { A Faculty member keens on choosing the appropriate method of assessment, according to the } \\
\text { characteristics of students }\end{array}$ & 3.11 & 1.43 & Moderate \\
\hline \multicolumn{2}{|r|}{$\begin{array}{l}\text { The Second standard: faculty members should be skilled in developing assessment methods appropriate } \\
\text { for instructional decisions }\end{array}$} & 3.20 & 1.12 & Moderate \\
\hline 5 & When Faculty member designs a test, he ensures diversity of test questions & 3.20 & 1.34 & Moderate \\
\hline 6 & $\begin{array}{l}\text { A Faculty member takes into account at building the test that includes all instructional goals of } \\
\text { course }\end{array}$ & 3.39 & 1.28 & Moderate \\
\hline 7 & $\begin{array}{l}\text { When Faculty member designs a test, he ensures the comprehensiveness of the scientific content } \\
\text { of course }\end{array}$ & 3.14 & 1.25 & Moderate \\
\hline 8 & A Faculty member estimates characterized by objectivity and justice & 3.15 & 1.25 & Moderate \\
\hline 9 & A faculty member develops to know how to design methods of assessing students & 3.29 & s1.19 & Moderate \\
\hline 10 & A faculty member is Characterized accuracy when assessing the level of student performance & 3.02 & 1.27 & Moderate \\
\hline \multicolumn{2}{|r|}{$\begin{array}{l}\text { The Third standard: faculty members should be skilled in administering, scoring, and interpreting the } \\
\text { results of both commercially produced and teacher-produced assessment methods }\end{array}$} & 3.10 & .81 & Moderate \\
\hline 11 & A faculty member Identifies instruction on the test paper questions clearly & 3.12 & 1.14 & Moderate \\
\hline 12 & A Faculty member applies the test instructions fairly among all students & 3.15 & 1.11 & Moderate \\
\hline 13 & A faculty member ensures not to explain the questions to some students without the other & 3.07 & 1.13 & Moderate \\
\hline 14 & $\begin{array}{l}\text { A faculty member determines the same time to start and end of the test to all students without } \\
\text { exception }\end{array}$ & 3.02 & 1.08 & Moderate \\
\hline 15 & A faculty member Identifies typical of the answer to the test & 2.98 & 1.07 & Moderate \\
\hline 16 & A faculty member Committed typical answer in the test correction & 2.89 & 1.24 & Moderate \\
\hline 17 & A faculty member Reviews results of the analysis of the test scores of students statistically & 3.20 & 1.28 & Moderate \\
\hline No & standards -Item & Mean & Std. Deviation & Levels \\
\hline 18 & $\begin{array}{l}\text { A faculty member Benefits from the analysis of the test results in addressing the weaknesses and } \\
\text { strengths of students }\end{array}$ & 3.15 & 1.04 & Moderate \\
\hline
\end{tabular}




\begin{tabular}{|c|c|c|c|c|}
\hline 19 & $\begin{array}{c}\text { A Faculty member takes into account students' activities in the course and active participation } \\
\text { next to their scores on tests when assessing }\end{array}$ & 3.35 & 1.14 & Moderate \\
\hline \multicolumn{2}{|r|}{$\begin{array}{l}\text { The Fourth standard: faculty members should be skilled in employment assessment results when making } \\
\text { decisions about improvement planning teaching, developing curriculum, improve academic performance }\end{array}$} & 3.16 & .88 & Moderate \\
\hline 20 & A faculty member Discusses causes of low achievement level with students & 3.32 & .95 & Moderate \\
\hline 21 & $\begin{array}{l}\text { A Faculty member takes the views of students about the causes of low achievement in the } \\
\text { development of teaching methods and improve their performance }\end{array}$ & 3.32 & .99 & Moderate \\
\hline 22 & $\begin{array}{c}\begin{array}{c}\text { A faculty member restores to consider the techniques and methods of teaching the course in light } \\
\text { of the results of students }\end{array} \\
\end{array}$ & 3.01 & 1.18 & Moderate \\
\hline 23 & A faculty member Inform concerned on the results of the students [administration - department] & 3.03 & 1.10 & Moderate \\
\hline 24 & $\begin{array}{l}\text { A faculty member offers a logical justification for the results of the students involved and the } \\
\text { students themselves }\end{array}$ & 3.13 & 1.22 & Moderate \\
\hline \multicolumn{2}{|r|}{$\begin{array}{c}\text { The Fifth standard: faculty members should be skilled in developing valid student grading procedures } \\
\text { that use student assessments }\end{array}$} & 3.05 & 1.02 & Moderate \\
\hline 25 & $\begin{array}{c}\text { A faculty member uses a variety of teaching methods [projects, assignments, classroom } \\
\text { activities, quizzes] in the Student Assessment }\end{array}$ & 3.01 & 1.12 & Moderate \\
\hline 26 & $\begin{array}{l}\text { A faculty member announces mechanism for assessing the level of student achievement and the } \\
\text { passing of the courses at the beginning of the course. }\end{array}$ & 3.10 & 1.19 & Moderate \\
\hline 27 & $\begin{array}{c}\text { A faculty member discusses mechanism of assessment the performance of the achievement of } \\
\text { students at the beginning of the course }\end{array}$ & 3.02 & 1.12 & Moderate \\
\hline \multicolumn{2}{|r|}{$\begin{array}{l}\text { The Sixth standard: faculty members should be skilled in communicating assessment results to students, } \\
\text { and To whom it may concern }\end{array}$} & 2.97 & 1.13 & Moderate \\
\hline 28 & A faculty member is committed objectivity when students tell their findings & 2.99 & 1.08 & Moderate \\
\hline 29 & A faculty member Keens at the speed of Report and students involved in the test results & 3.01 & 1.17 & Moderate \\
\hline 30 & $\begin{array}{l}\text { A faculty member Keens to inform students and concerned people the level of progress of his } \\
\text { students }\end{array}$ & 2.86 & 1.25 & Moderate \\
\hline 31 & A faculty member allows enough time for students to discuss their results in the test & 2.95 & 1.17 & Moderate \\
\hline 32 & \begin{tabular}{|l|}
$\begin{array}{c}\text { A faculty member Keens on the credibility of the estimates so consistent with the real level of } \\
\text { students }\end{array}$ \\
\end{tabular} & 2.95 & 1.26 & Moderate \\
\hline 33 & A faculty member Keens to listen to the complaints of students with respect to their results & 3.08 & 1.31 & Moderate \\
\hline No & standards -Item & Mean & Std. Deviation & Levels \\
\hline \multicolumn{2}{|r|}{$\begin{array}{l}\text { The Seventh standard: faculty members should be skilled in recognizing unethical, illegal, and otherwise } \\
\text { inappropriate assessment methods and uses of assessment information }\end{array}$} & 3.06 & .99 & Moderate \\
\hline 34 & $\begin{array}{l}\begin{array}{c}\text { A faculty member Keens to respect the privacy of students at the announcement of the results of } \\
\text { assessment of their level of achievement. }\end{array} \\
\end{array}$ & 2.98 & 1.21 & Moderate \\
\hline 35 & $\begin{array}{l}\text { A Faculty member refuses to accept donations and gifts from the students as a way to increase } \\
\text { their grades in exams. }\end{array}$ & 3.01 & 1.26 & Moderate \\
\hline 36 & A faculty member do not resort to use the tests as a means of punishment for students & 2.98 & 1.21 & Moderate \\
\hline 37 & $\begin{array}{l}\text { A faculty member Keens to deal with students with transparency and objectivity when assessing } \\
\text { their level }\end{array}$ & 3.17 & 1.10 & Moderate \\
\hline 38 & $\begin{array}{l}\text { A faculty member Keens not to motivate some of the students during the assessment process } \\
\text { without the other }\end{array}$ & 3.15 & 1.09 & Moderate \\
\hline \multicolumn{2}{|r|}{ General mean } & 3.08 & .79 & Moderate \\
\hline
\end{tabular}


Table 5. Means, Std. Deviation and t-test according to the gender variable (males/ females)

\begin{tabular}{|c|c|c|c|c|c|c|}
\hline standards & gender & Mean & Std. Deviation & $\mathrm{t}$ & $\mathrm{df}$ & Sig. [2-tailed] \\
\hline \multirow{2}{*}{$\begin{array}{l}\text { The First standard: faculty members should be skilled in } \\
\text { choosing assessment options appropriate for instructional } \\
\text { decisions }\end{array}$} & Male & 3.46 & 1.09 & \multirow{2}{*}{9.17} & \multirow{2}{*}{321} & \multirow{2}{*}{$.000 *$} \\
\hline & Female & 2.37 & 1.01 & & & \\
\hline \multirow{2}{*}{$\begin{array}{l}\text { The Second standard: faculty members should be skilled in } \\
\text { developing assessment methods appropriate for instructional } \\
\text { decisions }\end{array}$} & Male & 3.63 & .95 & \multirow{2}{*}{8.59} & \multirow{2}{*}{321} & \multirow{2}{*}{$.000 *$} \\
\hline & Female & 2.64 & 1.10 & & & \\
\hline \multirow{2}{*}{$\begin{array}{l}\text { The Third standard: faculty members should be skilled in } \\
\text { administering, scoring, and interpreting the results of both } \\
\text { commercially produced and teacher-produced assessment } \\
\text { methods }\end{array}$} & Male & 3.43 & .61 & \multirow[b]{2}{*}{9.07} & \multirow[b]{2}{*}{321} & \multirow[b]{2}{*}{$.000 *$} \\
\hline & Female & 2.69 & .84 & & & \\
\hline \multirow{2}{*}{$\begin{array}{c}\text { The Fourth standard: faculty members should be skilled in } \\
\text { employment assessment results when making decisions about } \\
\text { improvement planning teaching, developing curriculum, } \\
\text { improve academic performance }\end{array}$} & Male & 3.28 & .71 & \multirow[b]{2}{*}{2.80} & \multirow[b]{2}{*}{321} & \multirow[b]{2}{*}{$.005^{*}$} \\
\hline & Female & 3.01 & 1.05 & & & \\
\hline \multirow{2}{*}{$\begin{array}{c}\text { The Fifth standard: faculty members should be skilled in } \\
\text { developing valid student grading procedures that use student } \\
\text { assessments }\end{array}$} & Male & 3.42 & .93 & \multirow{2}{*}{8.13} & \multirow{2}{*}{321} & \multirow{2}{*}{$.000 *$} \\
\hline & Female & 2.57 & .92 & & & \\
\hline \multirow{2}{*}{$\begin{array}{l}\text { The Sixth standard: faculty members should be skilled in } \\
\text { communicating assessment results to students, and To whom it } \\
\text { may concern }\end{array}$} & Male & 3.44 & 1.08 & \multirow{2}{*}{9.41} & \multirow{2}{*}{321} & \multirow{2}{*}{$.000^{*}$} \\
\hline & Female & 2.37 & .90 & & & \\
\hline standards & gender & Mean & Std. Deviation & $\mathrm{t}$ & df & Sig. [2-tailed] \\
\hline \multirow{2}{*}{$\begin{array}{l}\text { The Seventh standard: faculty members should be skilled in } \\
\text { recognizing unethical, illegal, and otherwise inappropriate } \\
\text { assessment methods and uses of assessment information }\end{array}$} & Male & 3.42 & .94 & \multirow{2}{*}{8.12} & \multirow{2}{*}{321} & \multirow{2}{*}{$.000 *$} \\
\hline & Female & 2.59 & .86 & & & \\
\hline \multirow{2}{*}{ General score } & Male & 3.44 & .60 & \multirow{2}{*}{10.79} & \multirow{2}{*}{321} & \multirow{2}{*}{$.000 *$} \\
\hline & Female & 2.62 & .76 & & & \\
\hline
\end{tabular}

Significant* $\mathrm{p}<0.05$

Table 6. Means, Standard deviation and T-test according to the college variable (Practical colleges / Theoretic colleges)

\begin{tabular}{|c|c|c|c|c|c|c|}
\hline standards & college & Mean & Std. Deviation & $\mathrm{t}$ & df & $\begin{array}{c}\text { Sig. } \\
\text { [2-tailed] }\end{array}$ \\
\hline \multirow{2}{*}{$\begin{array}{c}\text { The First standard: faculty members should be skilled in } \\
\text { choosing assessment options appropriate for instructional } \\
\text { decisions }\end{array}$} & Practical college & 3.45 & 1.09 & \multirow{2}{*}{8.96} & \multirow{2}{*}{321} & \multirow{2}{*}{$.000 *$} \\
\hline & Theoretic college & 2.38 & 1.03 & & & \\
\hline \multirow{2}{*}{$\begin{array}{c}\text { The Second standard: faculty members should be skilled in } \\
\text { developing assessment methods appropriate for instructional } \\
\text { decisions }\end{array}$} & Practical college & 3.62 & .95 & \multirow{2}{*}{8.45} & \multirow{2}{*}{321} & \multirow{2}{*}{$.000^{*}$} \\
\hline & Theoretic college & 2.65 & 1.10 & & & \\
\hline \multirow{2}{*}{$\begin{array}{c}\text { The Third standard: faculty members should be skilled in } \\
\text { administering, scoring, and interpreting the results of both } \\
\text { commercially produced and teacher-produced assessment } \\
\text { methods }\end{array}$} & Practical college & 3.43 & .61 & \multirow[b]{2}{*}{9.08} & \multirow[b]{2}{*}{321} & \multirow[b]{2}{*}{$.000^{*}$} \\
\hline & Theoretic college & 2.69 & .84 & & & \\
\hline \multirow{2}{*}{$\begin{array}{c}\text { The Fourth standard: faculty members should be skilled in } \\
\text { employment assessment results when making decisions } \\
\text { about improvement } \\
\text { planning teaching, developing curriculum, improve academic } \\
\text { performance }\end{array}$} & Practical college & 3.28 & .71 & \multirow[b]{2}{*}{2.76} & \multirow[b]{2}{*}{321} & \multirow[b]{2}{*}{$.006^{*}$} \\
\hline & Theoretic college & 3.01 & 1.04 & & & \\
\hline \multirow{2}{*}{$\begin{array}{c}\text { The Fifth standard: faculty members should be skilled in } \\
\text { developing valid student grading procedures that use student } \\
\text { assessments }\end{array}$} & Practical college & 3.41 & .93 & \multirow{2}{*}{7.99} & \multirow{2}{*}{321} & \multirow{2}{*}{$.000^{*}$} \\
\hline & Theoretic college & 2.58 & .93 & & & \\
\hline \multirow{2}{*}{$\begin{array}{c}\text { The Sixth standard: faculty members should be skilled in } \\
\text { communicating assessment results to students, and To whom } \\
\text { it may concern }\end{array}$} & Practical college & 3.44 & 1.08 & \multirow{2}{*}{9.31} & \multirow{2}{*}{321} & \multirow{2}{*}{$.000 *$} \\
\hline & Theoretic college & 2.38 & .90 & & & \\
\hline \multirow{2}{*}{$\begin{array}{l}\text { The Seventh standard: faculty members should be skilled in } \\
\text { recognizing unethical, illegal, and otherwise inappropriate } \\
\text { assessment methods and uses of assessment information }\end{array}$} & Practical college & 3.42 & .94 & \multirow{2}{*}{8.15} & \multirow{2}{*}{321} & \multirow{2}{*}{$.000 *$} \\
\hline & Theoretic college & 2.59 & .86 & & & \\
\hline \multirow{2}{*}{ General score } & Practical college & 3.44 & .60 & \multirow{2}{*}{10.67} & \multirow{2}{*}{321} & \multirow{2}{*}{$.000^{*}$} \\
\hline & Theoretic college & 2.62 & .77 & & & \\
\hline
\end{tabular}

${ }^{*} \mathrm{p}<0.05$. (Significant) 


\section{Discussion}

The current study aimed to evaluate the faculty members' skills in assessing student learning at the University of Najran as defined by the American educational organizations (NCME, AFT and NEA). To discuss the results is as follows

\subsection{Regarding Discussion of the Results of the First Question}

Degree of the employment of faculty members for assessment standards defined by the American educational organizations ( NCME , AFT and NEA ) in assessing student learning at the University of Najran from the view of point of students.

The results showed moderated level of the employment of faculty members for assessment standards defined by the American educational organizations (NCME, AFT and NEA) in assessing student learning at the University of Najran from the view of point of students. This result is consistent with the study of [ 35, 26,27,28, 29, 19 and 31] that showed that the skill level of assessment achievement among faculty members was moderate, however, it is not consistent with the study of [9, and 32] that showed low level of the employment of international standards for scientific education assessment standards in assessing student learning. In addition, this result varies with the results of a study of [21], which showed high level of teachers' commitment to national standards for teachers in the assessment of student learning.

This difference may be due to sampling, where the sample of current study consisted of students while previous studies samples consisted of faculty members or teachers. No doubt that faculty members' judgment on their performance may be non-objective. In addition, some teachers may falsify their responses to give a positive image for their performance. In order to avoid this, the researchers in this study applied their study to a sample of students.

\subsection{Regarding Discussion of the Results of the Second Question}

Statistically significant differences in the employment of faculty members for assessment standards defined by the American educational organizations (NCME , AFT and NEA ) in assessing student learning at the University of Najran according to the gender variable [student males/ student females].

The results showed that there are statistically significant differences in the employment of faculty members for every assessment standards defined by the American educational organizations (NCME, AFT and NEA) in assessing student learning at the University of Najran According to the gender variable in favor of males. This result may be due to the diversity of experience and opportunities of the university to hire qualified male faculty. Choice opportunities for females are less, and that some of these practices associated with instructions and courses description, so faculty is keen on them and present them in a direct way for male students while presented to female students through television network. [26]

Thus, the direct relationship [face to face], which is between faculty members and male students was the main reason for these differences, as it provides an opportunity for faculty members to achieve good communication with students, and in the diversification of assessment methods.

\subsection{Regarding Discussion of the Results of the Third Question}

Statistically significant differences in the employment of faculty members for assessment standards defined by the American educational organizations (NCME, AFT and NEA ) in assessing student learning at the University of Najran according to the college variable [Practical college / Theoretic college].

The results showed that there are statistically significant differences in employing of faculty members for every assessment standards defined by the American educational organizations (NCME, AFT and NEA) in assessing student learning at the University of Najran according to the college variable in favor of practical college. These differences may be due to the nature of the courses taught in practical college, that requires faculty members to use alternative assessment strategies based on scientific principles and methodology, to ensure the quality of the educational process [1,3 and 4], as well as the need for diversity in modern assessment methods, so that not only the approved assessment method on paper and pencil as is common in many of our schools and universities, but also the use of other assessment methods based on performance, such as presentation, demonstration, communication, projects, assignments, quizzes, classroom activities, and observing the student behavior in the classroom, and in Laboratories.

This result is not consistent with the results of a study of [26, 30 and 37] that showed differences in assessment practices in favor of theoretic college. This difference is maybe due to the different target learning assessment standards in the current study and the instrument used.

\section{Conclusions}

In light of the current study's results, the study recommends that the faculty members should enroll in workshops and training courses and be briefed about updates in their specialization and assessment methods and the improvement of assessment standards by the faculty members in assessing student learning. Moreover, faculty members should be aware of the importance of employing 
alternative assessment methods helping them to make right educational decisions based on the results of the assessment process, and achieve good communication with students.

\section{Acknowledgements}

This research project is funded by the Deanship of Scientific Research at Najran University, Kingdom of Saudi Arabia [NU/SHED/15/079].

\section{REFERENCES}

[1] Adams, T., and Hsu, J., Classroom assessment: Teachers conceptions and practices in mathematics, School Science and Mathematics, 98 [4], 174-180, 1998.

[2] Al Basher A., and Areej E., [2012]. Employment alternative strategies and tools in assessing learning mathematics and Arabic in Jordan, Jordan: Journal of Educational and Psychological Sciences, Vol. 13, No. 1.

[3] Al Ababneh, M., .Evaluation of Yarmouk university students to the practices of faculty in the assessment of their students' achievement, unpublished master's thesis, Yarmouk University Jordan, 1998

[4] Al Ghamdi, S., Evaluation of the performance of teachers of natural science in middle school in the light of international standards for scientific education, Ph.D. thesis unpublished, Umm Al Qura University, Saudi Arabi, 2010.

[5] Al Mahasna, I., and Mouhaidat, A., Authentic evaluation, El-Bahrain, Ministry of Education, Measurement and Evaluation Center, 2009.

[6] Al Massery Mohammed and Merhi, T., Private University students' attitudes towards evaluation methods, Jordan: Journal of Educational and Psychological Sciences, 1, vol., 8, 2007.

[7] Al Shrfee, E., The extent of the use of social studies teachers to methods and tools of evaluation strategy based on performance in key stage and the problems of use from their perspective, unpublished Master Thesis, Mutah University, Karak, Jorda,2007.

[8] Al Smadi, M., Evaluation of faculty's practices in assessment students' academic achievement, International Journal of Education, VOL. 8, no. 1, pp 34-42,2016.

[9] Al Zahrati M., Suggested Proposal to improve tools to measure student achievement in accordance with the total quality standards ministry of education, Ph.D. thesis Unpublished, the Kingdom of Saudi Arabia,2009.

[10] Allen, d., and Flippo, R., Alternative assessment in the preparation of literacy educators: Responses from student, Reading Psychology, 23, 15-26, 2002.

[11] Bader, B., Recent trends in evaluating the sports knowledge, practical education magazine, No. 13, Vol. 2 pp 65-114, 2010 .
[12] Craw, K., Performance assessment practces: A case study of science teachers in A Suburban high school setting, Doctoral Study, Columbia University, 2009.

[13] Fritz, C., The level of teacher involvement in the Vermont mathematics Portfolio assessment process and instructional practices in grade 4 classroom, Dissertation Abstracts, $\mathrm{PhD}$, University of New Hampshire, USA,2001.

[14] Gerges, B., Degree teachers Zarqa Governorate's commitment to national standards for teachers in the assessment of student learning, Jordan: Islamic University of Educational and Psychological Studies Journal, Volume 21, Issue I, pp 535-566 2013

[15] Gipps, C., Quality assurance in teachers' assessment. ERIC Document Reproduction Service [No. ED372086], 1994.

[16] Gray D .Handbook of classroom assessment: Learning, Adjustment, and Achievement, Academic press, 1996.

[17] Hamdan A., The extent of use and the diversification of the Arabic language teachers in methods and tools for evaluating students through public education in Jordan, Journal of Educational Research Center, University of Qatar, 0.13 [7] n pp 141-17, 1998.

[18] Jackson, M., Elementary classroom assessment practices: Method, Application and Influence, Doctoral Study, Walden University, Mennesota, U.S.A., from ProQuest, 2009.

[19] Jonsson, A., Baartman ,L., Lennurg ,S., Estimating the Quality of performance assessments: The case of an interactive Examination for Teacher competencies, Learning Environments Research, vol. 12 n3 p225 - 241,2009.

[20] King Abdullah bin Abdul Aziz Public Education Development Project .The objectives of education development project, the project site on the net www.tatweer.edu.sa/page/home.aspx: // ttp, 2005.

[21] Lanting, A.,. An empirical study of district-wide K-2 performance assessment program: Teacher practices, information gained, and use of assessment results, Dissertation Abstracts, $\mathrm{PhD}$, University of LLinois at Urbana-Champaign, USA, 2000.

[22] Mahmoud, W.,; Khawaldeh, A., and Kaplan Y.,. The availability of educational assessment standards in the world of measurement and evaluation methods used at the mathematics teachers from their perspective, Al-Azhar University: Journal of the College of Education, , the number of 14,2009

[23] Medall, B., .Methods and practices assessment for the Study of biology for grades IX and X key from the standpoint of biology teachers in the provinces of Tulkarem and Qalqiliya, unpublished Master Thesis, El-Watanaa Najah University, Nablus, Palestine, 2000

[24] Medina,N., Neill.D., Fallout from the Testing Explosion: How 100 Million standardized Exams undermine Equity and Excellence in America's public schools . National center for Fair and open Testing, 1990.

[25] Mertler, C.,. Assessing student performance- a descriptive study of the classroom assessment practices of OHIO teachers, Bowling Green State University, U.S.A, 2000. 
[26] Murad, H., Evaluation methods of the teachers of the first cycle of primary education in educational assessment system, Journal of Educational and Psychological Sciences, 2 [4], pp 192-19, 2001.

[27] Napoli, A., and Raymond, L., How reliable are our assessment data?: A comparison of reliability of data produced in graded and un-graded conditions. Research in Higher Education, 45[8], 921-929, 2004.

[28] National team for evaluation: Evaluation strategies and tools: the theoretical framework, the Department of examinations and tests, Jordan: Ministry of Educatio, 2004.

[29] Qawasmeh, A., Student' evaluation to the practices of faculty in the assessment of their students' achievement in the university of Bahrain, Assuit University Journal, 23[1], 22-39, 2007.

[30] Shough, L., Standards-based teacher evaluation: A professional development tool for improving instruction, Ed,D, Dissertation, Arizona State University, U.S.A, 2010.

[31] Stes, A., Coertjens, L., Van Petegem, P., Intructional development in higher education: Impact on teachers' teaching behavior as perceived by students. Instructional Science, 41 [6], 1103-1126, 2013.

[32] Suleiman, S., Practices of faculty at the university of Tabuk in the assessment of their students' achievement, Umm Al Qura Journal for Psychological and Educational Sciences, 2[2], 78-110, 2010.
[33] Svinicki, M., Authentic assessments: Testing in reality, New Directions for Teaching and Learning, 100[4], 23-29, 2004.

[34] Tomlinson, C., How to differentiate instruction in mixed-ability classrooms, Alexandria, VA: Association for Supervision and curriculum Development, 2001.

[35] Yazareth, A., and Mohammed A., The extent of the use of science teachers to the tenth grade to assess student learning strategies in the light of the knowledge-based economy in Jordan's development plan, Umm Al Qura University, Journal of Educational and Psychological Science, No. 150, 2010.

[36] Zahrani, M., The reality of the performance of mathematics teachers at the secondary level in the light of contemporary professional standards in relation to the collection of their students, doctoral thesis unpublished, Umm Al Qura University, Saudi Arabia. 2008.

[37] Zakri, A., and Yahya, Q., The degree of using the contemporary evaluation standards by the faculty members at the university of Nalran, Saudi Arabia from their point of view, World Applied Sciences journal, 30 [1], 52-62, 2014

[38] Angelo, T and Cross, K.P. 1993. Classroom assessment techniques a handbook for college teachers. Jossey-Bass A Wiley Imprint, San Francisco, CA. Pp 427. 